\title{
Classification Profile and Registration Status of Care Institutions of Orphans and Poor Children in Malaysia
}

Azlini, C., Siti Hajar, A. R. \& Lukman, Z. M.

To Link this Article: http://dx.doi.org/10.6007/IJARBSS/v11-i8/10865

DOI:10.6007/IJARBSS/v11-i8/10865

Received: 25 June 2021, Revised: 30 July 2021, Accepted: 20 August 2021

Published Online: 27 August 2021

In-Text Citation: (Azlini et al., 2021)

To Cite this Article: Azlini, C., Siti Hajar, A. R., \& Lukman, Z. M. (2021). Classification Profile and Registration Status of Care Institutions of Orphans and Poor Children in Malaysia. International Journal of Academic Research in Business and Social Sciences, 11(8), 1541-1549.

\section{Copyright: (c) 2021 The Author(s)}

Published by Human Resource Management Academic Research Society (www.hrmars.com)

This article is published under the Creative Commons Attribution (CC BY 4.0) license. Anyone may reproduce, distribute, translate and create derivative works of this article (for both commercial and non-commercial purposes), subject to full attribution to the original publication and authors. The full terms of this license may be seen at: http://creativecommons.org/licences/by/4.0/legalcode

Vol. 11, No. 8, 2021, Pg. 1541 - 1549

Full Terms \& Conditions of access and use can be found at http://hrmars.com/index.php/pages/detail/publication-ethics 


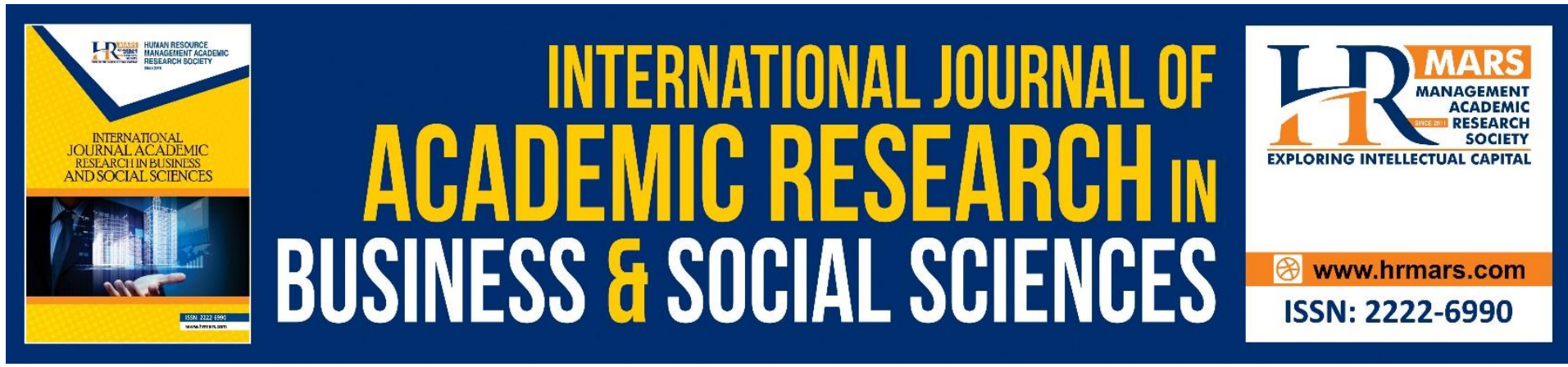

\title{
Classification Profile and Registration Status of Care Institutions of Orphans and Poor Children in Malaysia
}

\author{
Azlini, C., Siti Hajar, A. R. \& Lukman, Z. M. \\ School of Social Work, Faculty of Applied Social Science, Universiti Sultan Zainal Abidin, \\ Terengganu, Malaysia \\ Email: azlinichik@unisza.edu.my, hajarrauf@unisza.edu.my, lukmanzm@unisza.edu.my
}

\begin{abstract}
In providing shelter to orphans, the government, NGOs, private and religious bodies take the initiative to provide shelter, educational facilities and skills that are available to children from intact families. The existence of unregistered orphanage institutions contributes to a variety of problems such as lack of funds, institutions closing down and the lack of essential facilities in orphanage on safety and educational facilities. This article aims to provide a review of the profile of the orphanages in the state of Terengganu, Malaysia. This study used a qualitative research design consisting of structured interviews guided by a checklist on 49 institutions. The purposive sampling method was used in this study. The data obtained were analyzed using the frequency and percentages of the builtin checklists. The study found that only 48 institutions are registered and only 6 institutions are not registered with the government or NGO. Of the 28 institutions (57.1\%) are Tahfiz streams, 14 institutions (28.6\%) are Academic and Tahfiz streams and 7 institutions (14.3\%) are Academic streams. In conclusion, this study proposes that the institutions of care should be registered with the government or NGOs.
\end{abstract}

Keywords: Classification, Profile, Institutional Care, Orphans, Poor Children

\section{Introduction}

The development of orphanages began with the involvement of the British colonial government (Awang et al., 2004). Orphanages play the role of guardians, educators and caregivers of orphans; owners, developers and administrators of orphanages and trustees of properties belonging to orphans and promoting welfare work to members of the public (Mahyuddin et al., 1993).

In providing shelter to orphans, the government, non-governmental organizations (NGO), private and religious bodies take the initiative to provide housing, educational facilities and skills that are available to children with intact families (Awang, Sayuti, Jamaluddin, \& Chong, 2004). Children living in orphanages come from many backgrounds (FMT, 2019). They consist of children with one or both deceased parents, the poor and separated families. 
On average, 13,700 children were living in orphanages in Malaysia in 2018. This number does not take into account the existence of unregistered orphanages that are likely to reach as many as 50,000 orphaned children across Malaysia (Malaysia Kini, 2018). To date, there is no accurate data on the number of orphanages in Malaysia (Mohammadzadeh et al., 2019). One factor in this issue is the existence of unregistered orphanages.

The existence of unregistered orphanages contributes to a variety of issues such as lack of funds, the institutions closing down and the lack of essential facilities in the orphanages, particularly on safety and educational facilities (MyMetro, 2019). In addition, the existence of unregistered orphanages or orphanages that are noncompliant with the Malaysian Social Welfare Department (JKM) guidelines also contribute to the problem of orphans being exploited for the benefit of individuals (FMT, 2019). This situation shows that orphanages in Malaysia are not receiving the full support of relevant authorities, and are marginalized and exposed to negative risks (Mohammadzadeh at al., 2019).

This article aims to provide a review of the profile of orphanages in the state of Terengganu, Malaysia. The results of this survey will contribute to the knowledge on the profile of orphanages in Terengganu. This profile is important to obtain a clearer picture of the development of orphanages and furthering the establishment of orphanages in Malaysia.

\section{Literature Review}

The government plays an important role in providing services from a physical and social standpoint. In this regard, the Department of Social Welfare is a government agency that acts as a provider of care, protection and education services to orphans in Malaysia (Awang et al., 2004). In addition, the JKM will provide funds to cover the expenses of orphans, as well as donations and financial assistance from outside parties concerned about the welfare of orphans.

The Government of Malaysia provide funds to many Voluntary Welfare Organizations every year. In 2013, the Government awarded RM28,011,613 to 254 Voluntary Welfare Organizations. These include the orphanages, the disabled, poor families, the elderly, single mothers, and victims of disaster. Out of the total amount, RM8,147,800 was given to orphanages (Mohd, Ibrahim \& Baharudin, 2018). This allocation is provided to ensure the continued success of NGOs in providing quality care at orphanages in Malaysia.

In addition to providing protection and care services, orphanages also provide education services to orphans. Since the 15th century, the establishment of Malaysian orphanages has been heavily influenced by Islamic teachings, especially for orphanages in Peninsular Malaysia (Azlini et al., 2020). In addition to education in the academic stream, the Islamicbased education is also provided in orphanages such as the pondok (small hut) education system, tahfizs and madrasahs that emphasizes on learning based on the Quran and Arabic language.

\section{Research Methodology}

This study used secondary data and a qualitative research design with structured interviews guided by a checklist. This study has received a research ethics approval from the Faculty Evaluation Committee of Universiti Sultan Zainal Abidin (UniSZA) to conduct the study. 
To obtain information regarding orphanages in Terengganu, the researcher searched through the lists of care institutions from the Welfare Department, the Registrar of Societies (ROS), the Companies Commission of Malaysia (SSM), and the Islamic Religious Council and Malay Customs Council (MAIDAM). In addition, the list of institutions were also obtained through systematic searches on social media such as Facebook, official websites, newspapers and magazines. Furthermore, information from the public was also used to obtain a list of care institutions that housed orphans throughout Terengganu, Malaysia.

The purposive sampling method was used in this study. The inclusion criteria were the care institution should be a residential institution that houses poor orphans while being established in the state of Terengganu, Malaysia. The information is taken into account are institution name, district, institution ownership, institution registration status and institution type.

To get a deeper look at the institution's profile, a qualitative study in the form of a checklist-guided interview was used. A checklist is a set of questions (Karges-Bone, 2000; De Vaus, 2002) that contains items needed, things to do and things to consider that are used to review everything that needs to be done, has been and will be (Council Dictionary, 2005) either formal or informal (British Columbia Institute of Technology, 2010; McCain \& Tobey, 2004) or systematically and un-systematically. The checklist in the study was used to identify practices of the management of care institutions that shelters poor orphans on a regular basis. The types of checklists used in this study were dichotomous questions and multiple nominal responses (De Vaus, 2002) in order to obtain regular and systematic data from respondents.

The data collection procedure of this study involves firstly getting the respondent's consent to participate in this study. Respondents who agreed to participate in this study were required to sign informed consent. In the informed consent, information regarding the objectives of the study, the right of the respondent to withdraw from the study, not answering any questions, the information of the researcher and the purpose of the study were provided. After signing the informed consent, the respondents were interviewed by the researcher. Structured interviews using the checklist took approximately 60 minutes for each respondent. All information obtained from the respondents were recorded using the audio recording machine and checklist form.

The data obtained were analyzed using frequency and percentage based on the built-in checklist. To ensure the accuracy of the data collected, peer debriefing was conducted among the researchers. Peer debriefing is a technique that requires researchers to analyze data and then compare answers to ensure the accuracy of their answers (Guba, 1981).

\section{Result}

Table 1 shows the profile of institutions and streams of care institutions that house orphans and the poor in the state of Terengganu, Malaysia as a whole. There were 49 care institutions that housed poor orphans willing to cooperate in this study. 


\begin{tabular}{|c|c|c|c|c|c|c|c|c|}
\hline \multirow[b]{2}{*}{ No } & \multirow[b]{2}{*}{ Name of Institutions } & \multirow{2}{*}{$\begin{array}{l}\text { Instituti } \\
\text { onal } \\
\text { Owners } \\
\text { hip }\end{array}$} & \multicolumn{5}{|c|}{ Registration Status } & \multirow[b]{2}{*}{$\begin{array}{l}\text { Institutional } \\
\text { Stream }\end{array}$} \\
\hline & & & $\begin{array}{l}\mathrm{JK} \\
\mathrm{M}\end{array}$ & $\begin{array}{l}\text { MAID } \\
\text { AM }\end{array}$ & $\begin{array}{l}\mathrm{R} \\
\text { OS }\end{array}$ & $\begin{array}{l}\text { SS } \\
M\end{array}$ & $\begin{array}{l}\text { Not } \\
\text { Registere } \\
\text { d }\end{array}$ & \\
\hline 1 & Maahad Tahfiz As-Syifa' & NGO & No & No & No & No & Yes & Tahfiz \\
\hline 2 & $\begin{array}{l}\text { Akademik Tahfiz Baitul } \\
\text { Ulum }\end{array}$ & NGO & No & No & No & No & Yes & Tahfiz \\
\hline 3 & $\begin{array}{l}\text { Institut Tahfiz Al-Quran } \\
\text { Al-Mizan }\end{array}$ & NGO & No & Yes & No & No & No & $\begin{array}{l}\text { Academic and } \\
\text { Tahfiz }\end{array}$ \\
\hline 4 & Maahad Darul Quran & NGO & No & Yes & No & No & No & $\begin{array}{l}\text { Academic and } \\
\text { Tahfiz }\end{array}$ \\
\hline 5 & Madrasah Darul Ansar & NGO & No & Yes & No & No & No & Tahfiz \\
\hline 6 & $\begin{array}{ll}\text { Madrasah } & \text { Moden } \\
\text { Maidam } & \\
\end{array}$ & NGO & No & Yes & No & No & No & Tahfiz \\
\hline 7 & Madrasah Hafizatul Akmal & NGO & No & No & No & $\begin{array}{l}\text { Ye } \\
\mathrm{s}\end{array}$ & No & Tahfiz \\
\hline 8 & $\begin{array}{l}\text { Madrasah Mazahirul } \\
\text { Ulum }\end{array}$ & NGO & No & Yes & No & No & No & $\begin{array}{l}\text { Academic and } \\
\text { Tahfiz }\end{array}$ \\
\hline 9 & $\begin{array}{l}\text { Akademik Tahfiz Al-Quran } \\
\text { Azzawawi }\end{array}$ & NGO & No & No & $\begin{array}{l}\text { Ye } \\
\mathrm{s}\end{array}$ & No & No & $\begin{array}{l}\text { Academic and } \\
\text { Tahfiz }\end{array}$ \\
\hline 10 & Pondok Darussalam & NGO & No & Yes & No & No & No & Tahfiz \\
\hline 11 & $\begin{array}{ll}\text { Pondok } & \text { Raudhatul } \\
\text { Muhammadi } & \\
\end{array}$ & NGO & No & No & No & No & Yes & Tahfiz \\
\hline 12 & $\begin{array}{ll}\text { Madrasah } & \text { Ta'alim } \\
\text { Wattarbiyah } & \\
\end{array}$ & NGO & No & Yes & No & No & No & Tahfiz \\
\hline 13 & Madrasah Ibtidai & NGO & No & Yes & No & No & No & Tahfiz \\
\hline 14 & $\begin{array}{l}\text { Madrasah } \quad \text { As-Sirotol } \\
\text { Mustakim }\end{array}$ & NGO & No & No & No & No & Yes & Tahfiz \\
\hline 15 & $\begin{array}{l}\text { Madrasah Ad-Diniah Al- } \\
\text { Islamiah }\end{array}$ & NGO & No & Yes & No & No & No & Tahfiz \\
\hline 16 & $\begin{array}{l}\text { Maahad Tahfiz Al-Quran } \\
\text { Al-Azhar }\end{array}$ & NGO & No & Yes & No & No & No & Tahfiz \\
\hline 17 & $\begin{array}{ll}\text { Madrasatul } & \text { Quran } \\
\text { Kubang Bujuk } & \\
\end{array}$ & NGO & No & Yes & No & No & No & Academic \\
\hline 18 & Al-Hijrah & NGO & $\begin{array}{l}\text { Ye } \\
\mathrm{s}\end{array}$ & Yes & $\begin{array}{l}\text { Ye } \\
\mathrm{s} \\
\end{array}$ & No & No & Academic \\
\hline 19 & Asnaf As-Solehah & NGO & No & No & $\begin{array}{l}\text { Ye } \\
\mathrm{s}\end{array}$ & No & No & Tahfiz \\
\hline 20 & $\begin{array}{l}\text { Pusat Tahfiz Darul } \\
\text { Mahabbah }\end{array}$ & NGO & No & No & $\begin{array}{l}\text { Ye } \\
\mathrm{s}\end{array}$ & No & No & Tahfiz \\
\hline 21 & Pondok At Taqwa & NGO & No & Yes & No & No & No & Tahfiz \\
\hline 22 & Raudhatul Hijrah & NGO & No & No & $\begin{array}{l}\text { Ye } \\
\mathrm{s}\end{array}$ & No & No & Tahfiz \\
\hline 23 & $\begin{array}{l}\text { Pusat Tarbiyyah Nurul } \\
\text { Iman }\end{array}$ & NGO & No & No & $\begin{array}{l}\text { Ye } \\
\mathrm{s}\end{array}$ & No & No & Tahfiz \\
\hline
\end{tabular}


INTERNATIONAL JOURNAL OF ACADEMIC RESEARCH IN BUSINESS AND SOCIAL SCIENCES

Vol. 11, No. 8, 2021, E-ISSN: 2222-6990 @ 2021 HRMARS

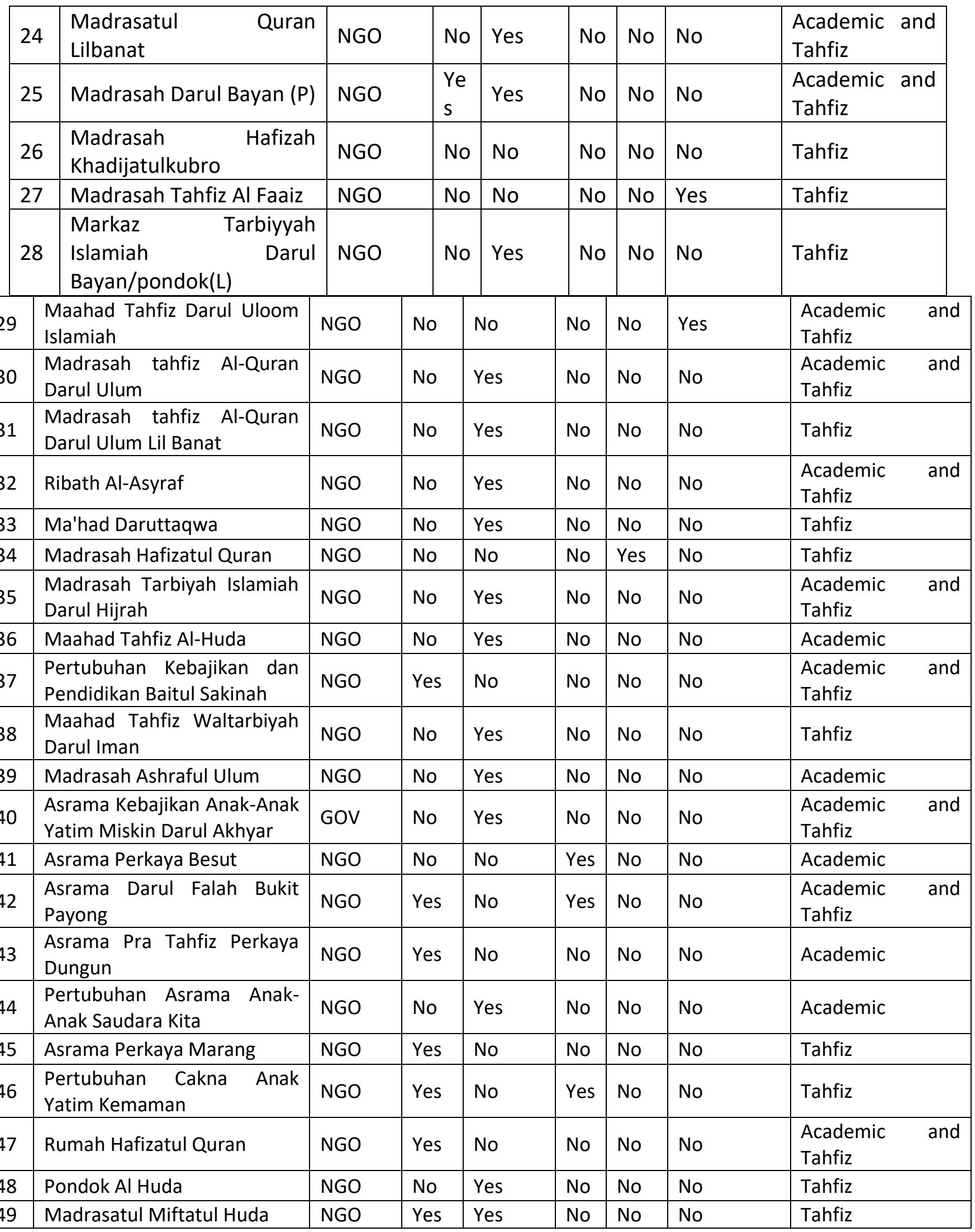

Table 1: Profile of Institutional Care for Orphans and Poor Children 
Table 2 shows the frequency distribution of the status of enrolment of care institutions that house poor orphans. A total of $28(57.1 \%)$ institutions were registered with MAIDAM, 9 (18.4\%) institutions were registered with JKM and ROS, 2 (4.1\%) institutions were registered with SSM and $6(12.2 \%)$ institutions were not registered with any party.

\begin{tabular}{|l|l|l|l|}
\hline No & Registration Status & Frequency & Percent \\
\hline $\mathbf{1}$ & MAIDAM & $\mathbf{2 8}$ & $\mathbf{5 7 . 1}$ \\
\hline 2 & JKM & 9 & 18.4 \\
\hline 3 & ROS & 9 & 18.4 \\
\hline 4 & SSM & 2 & 4.1 \\
\hline $\mathbf{5}$ & Not Registered & $\mathbf{6}$ & $\mathbf{1 2 . 2}$ \\
\hline
\end{tabular}

Table 2: Frequency Distribution of Institutional Care Registration Status of Orphans and Poor Children in 2018

Table 3 shows the frequency distribution of the institutional streams of care institutions that house poor orphans. Of the 28 (57.1\%) institutions were Tahfiz streams, 14 (28.6\%) institutions were Academic and Tahfiz streams and 7 (14.3\%) institutions were Academic streams.

\begin{tabular}{|l|l|l|l|}
\hline No & Institutional Stream & Frequency & Percent \\
\hline 1 & Tahfiz & $\mathbf{2 8}$ & $\mathbf{5 7 . 1}$ \\
\hline 2 & Academic and Tahfiz & 14 & 28.6 \\
\hline 3 & Academic & 7 & 14.3 \\
\hline
\end{tabular}

Table 3: Frequency Distribution of Institutional Care Placing Orphans and Poor by Stream, 2018

\section{Discussion and Conclusion}

According to table 1, a total of 48 orphanages under NGOs and only one is owned by the government. A total of 28 orphanages (57.1\%) are registered with Maidam and there are 6 $(12.2 \%)$ orphanages that are not registered with any party whether MAIDAM, JKM, ROS and SSM. Meanwhile, the most orphanages in the State of Terengganu are Tahfiz orphanages of 28 (57.1\%).

The failure of unregistered orphanages will cause problems that will affect the development of orphanages (Mohammadzadeh, Awang, Ismail, Kadir Shahar, 2019; Frimpong, 2021). In addition, the lack of legal registration also contributes to the government's difficulty in monitoring the activities of orphanages in Terengganu and Malaysia as a whole (Campos \& Alcoforado, 2018; Lyneham \& Facchini, 2019; Sochos \& Al - Jasas, 2020). This can lead to illegal activities such as begging activities (Harian Metro, 2019; Hasibuan et al., 2020). The existence of unregistered orphanage institutions contributes to a variety of problems such as lack of funds, institutions closing down and the lack of essential facilities in orphanage on safety and educational facilities (Rosenthal, 2018; Karandikar \& Charegaonkar, 2019).

Therefore, this study suggests that the care institution should be registered with the relevant government body or NGO that is the government or NGO (Bindman et al., 2019; Rateng, 2019; High, 2019). This is because with registration, it will make it easier for the government, the Ministry of Health, the Malaysian fire and rescue and local authorities to monitor and check the condition of the institution. 


\section{Acknowledgement}

We thank to Ministry of Education Malaysia and Center for Research Excellence and Incubation Management (CREIM), Universiti Sultan Zainal Abidin (UniSZA), Gong Badak Campus, Terengganu Malaysia for the permission to conduct this research, all the Child Institutional Social Care and respondents involved in this research for assistance that greatly assisted the research. This research was supported by Fundamental Research Grant Scheme

(FRGS) Project under Ministry of Education Malaysia -RR277 (FRGS/1/2018/SS06/UNISZA/02/3).

\section{References}

Abu Bakar, A. (2019). PIBG bertanggungjawab kutip derma, bukannya pelajar, kata timbalan Menteri. Free Malaysian Today (FMT) News. https://www.freemalaysiatoday.com/category/bahasa/2019/03/27/pibgbertanggungjawab-kutip-derma-bukannya-pelajar-kata-timbalan-menteri/.

Awang, A., Sayuti, R., Jamaluddin, Z., \& Chong, C. C. (2004). Simposium Kebangsaan Kebajikan Kanak-Kanak 2004. Kepentingan Terbaik kanak-kanak: Isu \& Cabaran. Permasalahan Anak Yatim di Institusi Kebajikan Anak Yatim.

Azlini, C., Siti Hajar, A. R., \& Lukman, Z. M. (2020). Konsep Penginstitusian Rumah Anak Yatim Miskin di Malaysia, 5, 1, 40-45.

Bindman, E., Kulmala, M., \& Bogdanova, E. (2019). NGOs and the policy-making process in Russia: The case of child welfare reform. Governance, 32(2), 207-222.

British Columbia Institute of Technology. (2002). Developing checklist and rating scales. Retirved from, http://www.northernc.on.ca/leid/docs/ja_developchecklists.pdf.

Chiew, H. (2018). Aina's story: Why M'sia needs to rethink how it treats institutionalised children. Malaysia Kini. https://www.malaysiakini.com/news/456532.

Campos, L. C., \& Alcoforado, F. (2018). Law, Government and Third Sector in Brazil: Improving deficient regulation to promote better accountability.

De Vaus, D. (2002). Survey in Social Research. (5th ed). London: Allen \& Unwin.

Frimpong-Manso, K. (2021). Funding orphanages on donations and gifts: Implications for orphans in Ghana. New Ideas in Psychology, 60, 100835.

Guba, E. G. (1981). Criteria for assessing the trustworthiness of naturalistic inquiries. Educational Communication and Technology Journal,29 (2),75- 91.

Hasibuan, E. J., Muda, I., Pulungan, W., \& Siregar, M. (2020). Exploitation Of Street-Having Children In Medan, North Sumatera Province. Technium Soc. Sci. J., 6, 188.

High, A. (2019). Non-governmental Orphan Relief in China: Law, Policy, and Practice. Routledge.

Karandikar, P., \& Charegaonkar, A. (2019). Aftercare for Young Adult Orphans.

Karges-Bone, L. (2000). Checklist for Everything!: Simple Assessment Tools for Student Projects, Grants and Parent Communication. Teaching \& Learning Company.

Lyneham, S., \& Facchini, L. (2019). Benevolent harm: Orphanages, voluntourism and child sexual exploitation in South-East Asia. Trends and Issues in Crime and Criminal Justice.

McCain, D. V., \& Tobey, D. D. (2004). Facilitation Basics. Alexandria: American Society for Training and Development.

Mohammadzadeh, M., Awang, H., Ismail, S., \& Shahar, K. H. (2019). Improving emotional health and self-esteem of Malaysian adolescents living in orphanages through Life Skills Education program: A multi-centre randomized control trial. PLOS ONE 14(12): e0226333. 
Mohd, A., Ibrahim, B., \& Baharudin, M. H. (2018). Charitable Endowment (Waqf) for the Benefit of Parentless Children in Malaysia: A Preliminary Study. IIUM Law Journal, 26(2), 433.

Rateng, J. (2019). Development Of A Web Based Spatial Information System For NonGovernmental Organizations In Nairobi County (Doctoral dissertation, University of Nairobi).

Rosenthal, E. (2018). The right of all children to grow up with a family under international law: implications for placement in orphanages, residential care, and group homes. Buff. Hum. Rts. L. Rev., 25, 65.

Sochos, A., \& Al-Jasas, N. (2020). Attachment provision in the Saudi orphanages: Exploring the narratives of residential staff. International Journal of Social Welfare, 29(3), 244-254. 